\section{Volumetric Microdetermination of Sulphonamides}

Volumetrische Mikrobestimmung von Sulfonamiden

Best. von Sulfonamiden; Volumetrie;

Verw. von Brommonochlorid

V. K. S. Shukla, S. Shukla, and J. P. Sharma

Department of Chemistry, University of Allahabad, India

Received September 9,1972 ; revised November 27, 1972

A rapid and convenient method for the determination of sulphonamides was based upon the reaction with bromine monochloride and titration of excess reagent by iodometry.

The method has been applied to the determination of sulphapyridine, sulphathiazole, sulphaguanidine

\section{Identification of Isothiocyanates (Mustard Oils) and Liquid Primary Amines via the Formation of 1-Substituted 2-Tetrazoline-5-thione}

Identifizierung von Isothiocyanaten (Senfölen) und flüssigen primären Aminen über die Bildung von 1-substituiertem 2-Tetrazolin-5-thion.

Nachw. von Isothiocyanaten und Aminen, primäre; Bildung von 1-subst. 2-Tetrazolin-5-thion.

\section{G. S. Johar}

Department of Chemistry, Vikramajit Singh Sanatan Dharma College, Kanpur-208002, India

Received July 21, 1972; revised November 18, 1972

A specific and reliable colour reaction has been found for the identification of the $-\mathrm{N}=\mathrm{C}=\mathrm{S}$ group. It is based on its reaction with azide, yielding a 1-substituted 2-tetrazoline-5-thione, which gives a yellow precipitate [1] on treatment with bismuth(III). Almost all isothiocyanates give this test. No interferences are caused by thiocyanates, thiols, sulphonic acids and water-insoluble thioureas. Ordinary thiourea (thiocarbamide) may interfere by a yellow colour, which however can be destroyed by pyridine. For the detection of a primary amine this is first converted to an isothiocyanate by reaction with diethylamine, carbon disulphide and hydrogen peroxide [2]. Solid amino compounds fail to react in this way. and sulphadiazine. The number of moles of $\mathrm{BrCl}$ consumed per mole of these compounds is $8,7,5$ and 7 , respectively. $2-10 \mathrm{mg}$ were determined with deviations of $\pm 1 \%$ on the average.

Procedure. An aliquot containing 2-10mg of the sample is placed in a $100 \mathrm{ml}$ iodine flask. Add $5 \mathrm{ml}$ of glacial acetic acid and $5 \mathrm{ml}$ of $\mathrm{BrCl}$ solution $\left(1.3917 \mathrm{~g} \mathrm{KBrO}_{3}+1.9835 \mathrm{KBr}\right.$ in $125 \mathrm{ml}$ of water, after cooling addition of $100 \mathrm{ml}$ of conc. hydrochloric acid and dilution to $500 \mathrm{ml}$ ), stopper and shake. Cool for $20 \mathrm{~min}$ in ice bath, wash stopper with $5 \mathrm{ml}$ of water, add $5 \mathrm{ml}$ of $15 \% \mathrm{KI}$ solution and titrate the liberated iodine with $0.02 \mathrm{~N}$ sodium thiosulphate solution using starch as indicator. Run a blank under the same conditions.

Dr. J. P. Sharma

Dept. of Chemistry

University of Allahabad

Allahabad, India

\section{Procedure}

Isothiooyanates. To $1-2$ drops or $25-50 \mathrm{mg}$ of the test compound add $25-50 \mathrm{mg}$ of sodium azide and $5 \mathrm{ml}$ of water, heat in a water bath for $10 \mathrm{~min}$ or until the volume is reduced to one half, add $2 \mathrm{ml}$ of $1 \% \mathrm{Bi}$ (III) nitrate or chloride solution and observe the development of a yellow precipitate which turns deep yellow or orange-yellow by adding a drop of pyridine. The treatment with bismuth and pyridine can also be carried out as a spot test on paper.

The following compounds gave positive results :

n-butyl, allyl, phenyl, p-chlorophenyl, p-bromophenyl, 2,4-dichlorophenyl, m-chlorophenyl, p-methylphenyl, benzyl, m-phenylene-di, p-phenylene-di, p,p'-diphenyl-di, and $\alpha$-naphthyl isothiocyanate.

Liquid Primary Amines. Add 1 drop of diethylamine, 2 drops of carbon disulphide and $2-3$ drops of $6 \%$ hydrogen peroxide to 2 drops of the sample. Isothiocyanate is formed by an exothermic reaction, also a small amount of $N, N^{\prime}$. disubstituted thiourea and free sulphur. To the mixture add $3-4 \mathrm{ml}$ of water and $25-50 \mathrm{mg}$ of sodium azide, heat for $5 \mathrm{~min}$, filter if necessary and test with bismuth(III) as above.

The following amines were tested and gave positive results : Ethyl, n-butyl, allyl, benzyl amine, aniline, o-toluidine, $\mathrm{m}$-toluidine, p-toluidine, p-phenetidine, and $\alpha$-naphthylamine (a solid).

Author's thanks are due to University Grants Commission, New Delhi, for financial assistance.

\section{References}

1. Johar, G. S., Agarwala, U.: Current Sci. 38, 492 (1969).

2. Johar, G. S., Agarwala, U., Rao, P. B. : Indian J. Chem. $8,759(1970)$.

Dr. G. S. Johar

Dept. of Chemistry

V.S.S.D. College

Kanpur-208002, India 